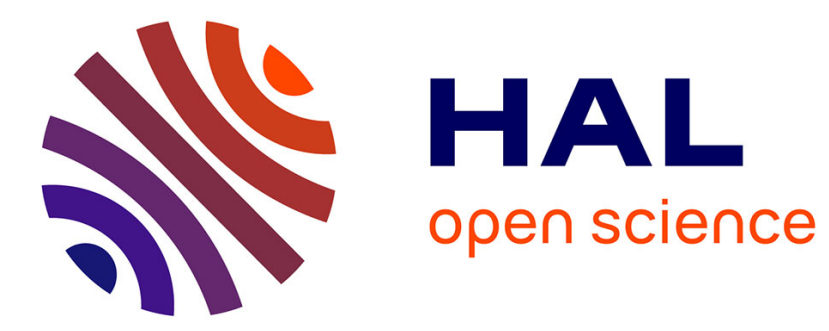

\title{
Research regarding the influence of axial electromagnetic pulsation of the liquid metal bath upon the characteristics of the weld
}

\author{
V. Miclosi, I. Tonoiu, G. Solomon
}

\section{- To cite this version:}

V. Miclosi, I. Tonoiu, G. Solomon. Research regarding the influence of axial electromagnetic pulsation of the liquid metal bath upon the characteristics of the weld. Journal de Physique IV Proceedings, 1993, 03 (C7), pp.C7-119-C7-122. 10.1051/jp4:1993717 . jpa-00251799

HAL Id: jpa-00251799

https://hal.science/jpa-00251799

Submitted on 1 Jan 1993

HAL is a multi-disciplinary open access archive for the deposit and dissemination of scientific research documents, whether they are published or not. The documents may come from teaching and research institutions in France or abroad, or from public or private research centers.
L'archive ouverte pluridisciplinaire HAL, est destinée au dépôt et à la diffusion de documents scientifiques de niveau recherche, publiés ou non, émanant des établissements d'enseignement et de recherche français ou étrangers, des laboratoires publics ou privés. 


\section{Research regarding the influence of axial electromagnetic pulsation of the liquid metal bath upon the characteristics of the weld}

\section{MICLOSI, I. TONOIU and G.H. SOLOMON}

Polytechnic Institute of Bucharest, Bucharest, Romania

Abstact

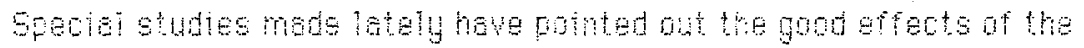

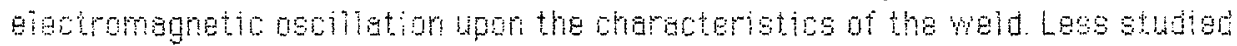

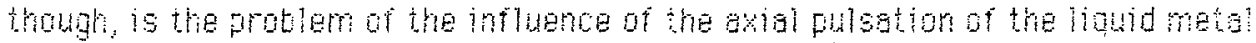
bath Gxial oschlation wpon the charactarstics of the weld when using externel megnetic rielo.

intruduction

The present paper trests actig the protiem.

The bastodogran of the verient is presented in fighe ? where:

i-electrode, 2-coll, 3-a drop af huld metal, 4-the electric are, 5-the

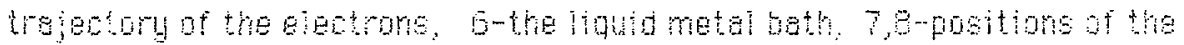

ioutoriot bing

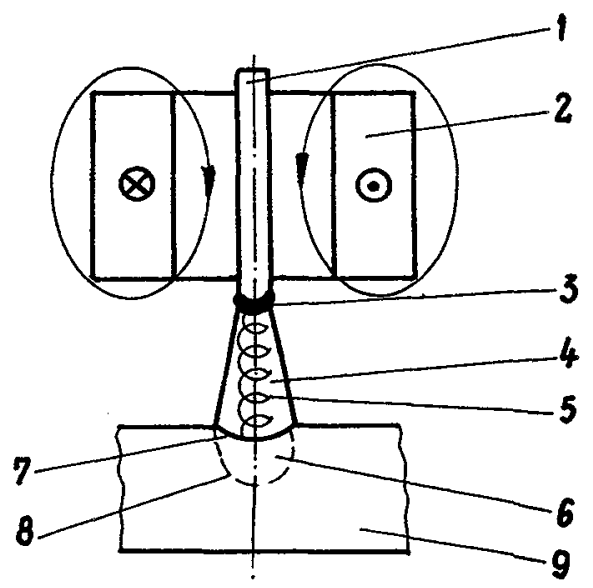

Fig. 1. The basic diagram of the akial pulsetion of the liquid metel bath 
Upon the action of the induction magnetic field $\mathrm{B}$, produced ty the coil 2 . cosxial with electrode 1 , snd supplied with a pulsoting tension the surfoce of the liquid metal bath 6 starts an oscillation mavement hiving the frequency of the supplied pulsations of the coil, reaching the positions 7 and $\mathrm{a}$. time, due to the radial components of the induction $B$, the electrone from the electric arc 4 describe a complex spiral mowement 5

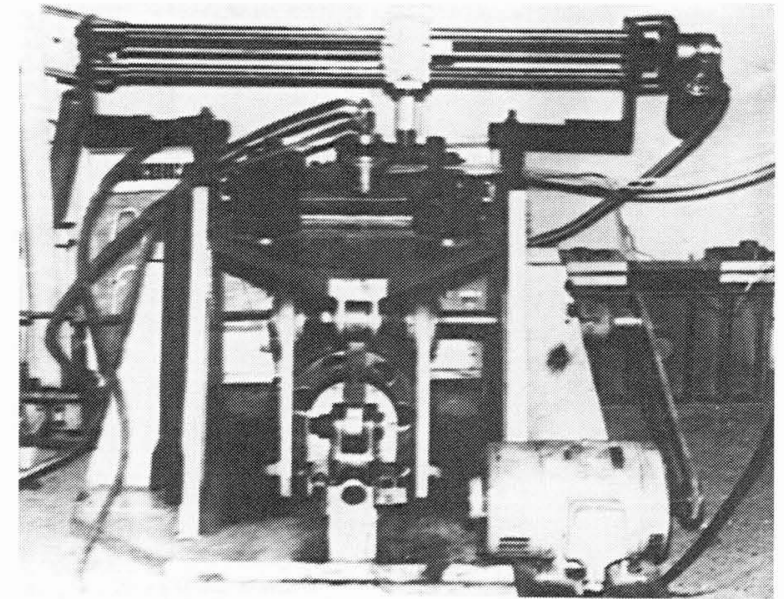

Fiq. 2. Stand for the measuring of the crecking tendency at hest.

In order to determine the influance of the phenomena described upon the geometrical parameters and upon the charecteristics of the weld experiments have been made, using a TIG welding heor with axial ritsetion of the liquid metsi both, tixed one stend for the meseuring of the cracking tendency gt heat, sepresented in Fig. 2.

\section{Experiments made}

T.6. welds have ben made without adotional materiel using test pleces of gueteritic steel, tupe w 1.4541 , havig the dimensons $200 \times 100 \mathrm{~m} 4 \mathrm{~mm}$, in the folowing situatians

i. nomal TIE Weld without magnetis field:

2. TiG weld with constint magnetic ileld:

3. TIG weld with pulsating rrequency of $5,10,15$ and $20 \mathrm{~Hz}$

The values of the magretic field induced, measured with the Hall sounding rod were 4,8 and $16 \mathrm{mT}$ respectively.

Eighteen tests have been made in order to study the influence of the anial pulsotion on the charscteristics of the weld, and 10 tests for the cracking tendency at heat, in the conditions mentioned above. For some of the tests for the cracking tendency at heat, Cu and sn were introduced in the weld from the outside, in order ta point aut the effects of these elements upon the cracking tendency at heat.

The tests were made for two distortion speeds (vo) that is 20 and $61 \mathrm{~mm} / \mathrm{min}$ respectively. 
The technological parameters used during the welding were the following:

the diameter of the tungsten electrode, $d=2.5 \mathrm{~mm}$;

-the welding current, $1 \mathrm{~s}=95-100 \mathrm{~A}$;

-the tension of the electric arc, Ua $=12-15 \%$;

-the gas flosw, $a=10$ limin:

the welding speed, $v s=20 \mathrm{~cm}$ min.

Aspects of the macrostructure and microstructure for some of the tests made arepresented in Fig. $3,4,5$ and 6 .

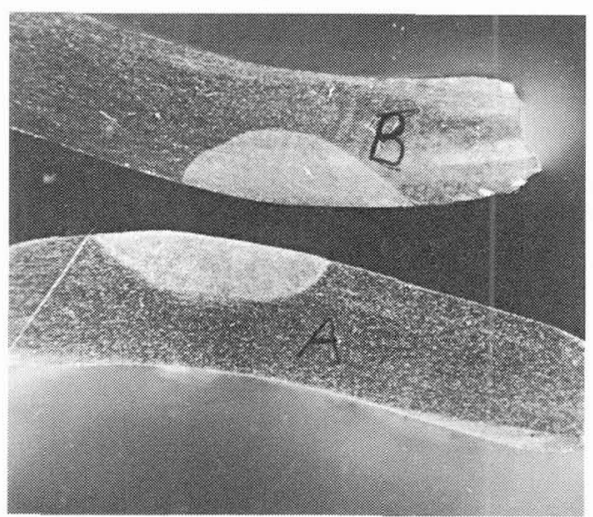

Fig.3 Macrostructure for a test for cracking tendency at hest A- with axial pulsetion B-without awis? pulsation

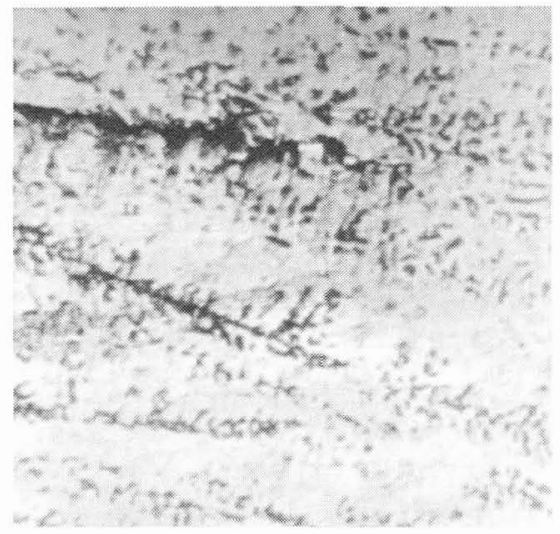

Fig. 5. Microstructure fur a test weld weild

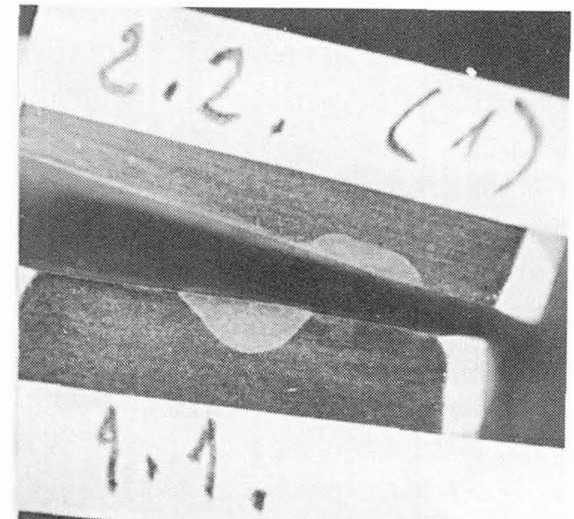

Fyg.4. Mecrostrocture for a test heid

1.1. Tl6 welding whout pusation

2. Tig welding with fubation

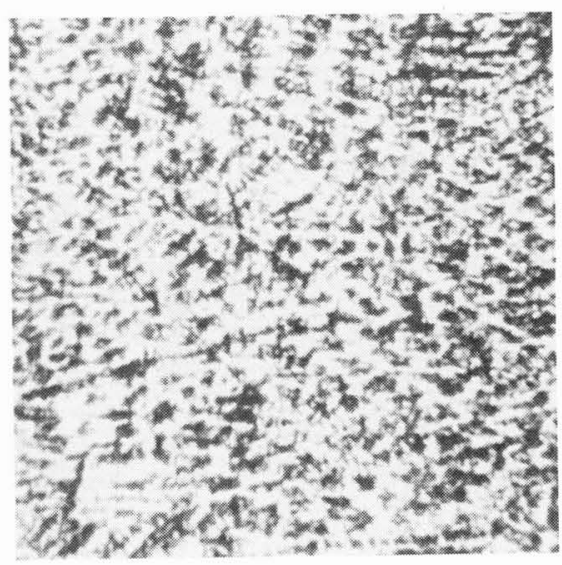

Fig. 6. Microstructure for a test. 


\section{Conclusions}

From the macroscopic analyeis of the welds, mode in the experimental conditions presented, we con draw the conclusiun that the presence of the eloctromagnetic axial pulsation of the electric arc, leads to a smaller penetration and the the anging of the width of the weld, a fawrouble effect from the point of wew of the cracking at hest, being well known the fact that the deep and narrow welds run a higher risk of craking at heat.

From the microscopic analyeis of the teste mate we con point out that the presence of the constant or variable magnetic field at frequences under $10 \mathrm{~Hz}$, lead to smaller grains as a result of the breaking of the dendrites.

The megsurements made did not distimctly point out this fact also because of the fact that the dimensions of the grains was considered between 2 limit viuesi.

Arove the frequency of $15 \mathrm{~Hz}$, the exterior aspocts of the weld is not adequate. and therefore, the range of the frequency must be telow $15 \mathrm{~Hz}$.

The electromegretic axial pulestion of the electric arc triggers a shal onger $1-2$ per cent of the content af ferrite.

The shollest hardness in the weld were obtained when weiting withont mogretic field, and in the case of pulsating magnetic field, the hardness raises at the same time the frequency does

The tests for creckig at hest manged to point out directiy the infience of the arial electromagnetic puleation uph the tendency of crakigat hest.

in the cose of onh one test mage with a constant mogretic iteld of amt the arsking dit not take olece, for al the other bses when in the welo ware

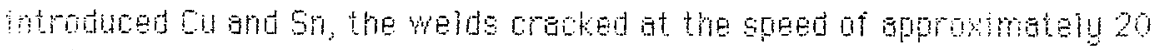
mirmin. the content af cabeing about $2 \%$

Al the ather somples had wible crots, even thotgh the defomation ened

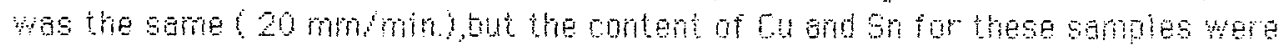
viel $5 \%$

Later research met be dibcted tomard the finding of the values af the fropuency and the intensity of the magnetic field for which the test pertomances con de obtained.

\section{References}

[1] WF Sovoge, Lhao Fang Tseng. walding Journal, 1 (1980).

[2] Efolkhort, Welding metallurgy of stainlese steel, New York, (1980).

[3] B.F.Dinon, R.H.Fhilips and. IC.Fitter, Crocking in the transvare strant test. Metal Construction, (1984). 